\title{
INCONSTITUCIONALIDADE DA VEDAÇÃO À CONCESSÃO DE TUTELAS \\ PROVISÓRIAS CONTRA A FAZENDA PÚBLICA NAS AÇÕES DE REPETIÇÃO DE INDÉBITO TRIBUTÁRIO ${ }^{1}$
}

\section{UNCONSTITUTIONALITY OF THE PROHIBITIONS TO GRANT PROVISIONAL JUDICIAL MEASURES AGAINST THE STATE IN TAX RECOVERY PROCEEDINGS}

Caio Neno Silva Cavalcante

Aluno Especial do Programa de Mestrado em Direito da Universidade Católica de Brasília (UCB) - Linha de Pesquisa de Direito, Estado, Tributação e Desenvolvimento. Bacharel em Direito pelo Centro Universitário de Brasília (UniCEUB). Bacharel em Engenharia de Controle e Automação pela Universidade de Brasília (UnB). Advogado. Belém, Pará, Brasil. E-mail: caionsc@gmail.com.

Cleucio Santos Nunes Doutor em Direito do Estado, Constituição e Justiça pela Universidade de Brasília (UnB). Mestre em Direito Ambiental pela Universidade Católica de Santos (UniSantos). Especialista em Direito Tributário e Processo Tributário pela Pontifícia Universidade Católica de São Paulo (PUC/SP). Professor do Mestrado no Programa de Pós-Graduação em Direito da Universidade Católica de Brasília (UCB). Professor da Graduação em Direito do Centro Universitário de Brasília (UniCEUB). Advogado. Santos, São Paulo, Brasil. E-mail: cleuciosnunes@gmail.com.

\footnotetext{
${ }^{1}$ Artigo recebido em 08/03/2020 e aprovado em 04/11/2020.
} 
RESUMO: Avalia-se a (in)constitucionalidade das vedações, impostas pela legislação e pela jurisprudência, à concessão de tutelas provisórias contra o Poder Público nas ações de repetição de indébito tributário. Para tanto, identifica-se os principais óbices doutrinários e prossegue-se à apresentação da racionalidade por trás das vedações em questão. Por último, passa-se à demonstração do fundamento constitucional do direito à repetição de indébito e à superação dos obstáculos à concessão de tutelas provisórias. É utilizado o método dedutivo, por meio de pesquisa realizada em legislação, doutrina e jurisprudência dos tribunais ao redor do país.

PALAVRAS-CHAVE: Tutelas provisórias. Repetição de indébito tributário. Efetividade de jurisdição. Jurisprudência dos tribunais superiores. Processo tributário.

\begin{abstract}
The (un)constitutionality of the prohibitions, imposed by legislation and jurisprudence, to the granting of provisional judicial measures against the State in tax recovery proceedings is evaluated. To this end, the main doctrinal obstacles to the use of provisional judicial measures against the State are identified and the rationality behind the prohibitions in question is presented. Finally, it is demonstrated that the right to recover undue taxes has a constitutional foundation, so that procedural obstacles to said recovery must be surpassed. The deductive method is used, through research carried out on legislation, doctrine and jurisprudence of courts around the country.
\end{abstract}

KEY WORDS: Provisional judicial measures. Tax recovery proceedings. Jurisdictional effectiveness. Superior courts jurisprudence. Tax Proceeding.

\title{
1 INTRODUÇÃO
}

Efetividade é o desempenho concreto da função social do Direito, de modo que "representa a materialização, no mundo dos fatos, dos preceitos legais e simboliza a aproximação, tão íntima quanto possível, entre o dever-ser normativo e ser da realidade 
social"2. Dentro do âmbito da efetividade, o termo jurisdição ganha novo significado, assumindo o dever de tutelar, em especial, os direitos fundamentais ${ }^{3}$.

Nesse sentido, Teori Zavascki, ao discorrer sobre a necessidade de se ponderar segurança jurídica e efetividade, afirma que "a fórmula para viabilizar a convivência entre segurança jurídica e efetividade da jurisdição é a da outorga de medidas de caráter provisório, que sejam aptas a superar as situações de risco de perecimento de qualquer um desses direitos" ${ }^{\prime 4}$ É nesse ambiente que ganha força o instituto da tutela provisória.

Prevista entre os arts. 294 e 311, do Código de Processo Civil de 2015 (CPC/2015), a tutela provisória é uma espécie de provimento liminar com fundamento constitucional ${ }^{5}$. Trata-se de prestação jurisdicional, sem caráter de definitividade, cujo objetivo é equalizar determinada situação jurídica antes que se torne extinto o direito que é objeto da lide $^{6}$. As tutelas provisórias, portanto, constituem vivaz exemplo de ponderação principiológica entre os valores da segurança jurídica e da efetividade jurisdicional.

Ao longo da história da produção legislativa brasileira, no entanto, começou a se delinear aquilo que se convencionou chamar "Sistema de proteção à Fazenda Pública", que pode ser definido como um conjunto de normas legais infraconstitucionais e precedentes judiciais que, com o objetivo de proteção ao erário, preveem vedações à concessão de medidas liminares, incluindo as tutelas provisórias, contra a Fazenda Pública.

\section{O SISTEMA DE PROTEÇÃO À FAZENDA PÚBLICA E OS ÓBICES DOUTRINÁRIOS À CONCESSÃO DE TUTELAS PROVISÓRIAS}

Em especial após a promulgação da Constituição Federal de 1988 (CF/88), quando se iniciou o processo de constitucionalização do Direito Processual no Brasil, parte da doutrina passou a defender que a interpretação literal dos dispositivos integrantes deste

\footnotetext{
${ }^{2}$ BARROSO, Luís Roberto. Curso de Direito Constitucional contemporâneo: os conceitos fundamentais e a construção do novo modelo. $4^{\mathrm{a}}$ ed. São Paulo: Saraiva, 2013, p. 243.

${ }^{3}$ MARINONI, Luiz Guilherme. Direito Fundamental de Ação. In: CANOTILHO, J. J. G., et al. Comentários à Constituição do Brasil. $2^{\mathrm{a}}$ ed. São Paulo: Saraiva Educação, 2018, p. 389.

${ }^{4}$ ZAVASCKI, Teori Albino. Antecipação de tutela. $2^{a}$ ed. São Paulo: Saraiva, 1999, p. 67-68.

${ }^{5} \mathrm{Na}$ doutrina, é comum encontrar referência ao fundamento constitucional das tutelas provisórias no art. $5^{\circ}$, $\mathrm{XXXV}, \mathrm{CF} / 88$, contudo, Teori Zavascki apresentava tese digna de nota, na qual defendia que, em verdade, o fundamento constitucional do instituto residiria no "próprio sistema constitucional organicamente considerado", visto que se trataria de mecanismo de concretização e harmonização de direitos fundamentais em conflito (ZAVASCKI, Teori Albino. Antecipação de tutela. $2^{a}$ ed. São Paulo: Saraiva, 1999, p. 61).

${ }^{6}$ MACHADO SEGUNDO, Hugo de Brito. Processo Tributário. $10^{a}$ ed. São Paulo: Atlas, 2018, p. 483.
} 
sistema, poderia ofender (i) o princípio da inafastabilidade da jurisdição estatal, positivado no art. $5^{\circ}, \mathrm{XXXV}, \mathrm{CF} / 88$, e todo seu corolário, composto pelo princípio da efetividade da tutela, pelo poder geral de cautela do juiz e pela duração razoável do processo (art. $5^{\circ}$, LXXVIII, CF/88); (ii) o princípio da isonomia (art. 5, caput, CF/88), bem como (iii) os valores de cooperação processual e celeridade que inspiraram o CPC/2015 ${ }^{7}$.

A discussão também não é pacífica na jurisprudência nacional. Nesse sentido, vale ressaltar o julgamento da ADI $n^{\circ} 1.576 / \mathrm{DF}$, pelo Supremo Tribunal Federal (STF), realizado em 1997. Na ocasião, o tribunal sintetizou dois pontos que, neste artigo, foram denominados “óbices doutrinários à utilização de tutelas provisórias contra a Fazenda Pública"8.

Tais pontos ficaram conhecidos como os principais obstáculos à concessão de medidas liminares contra o Poder Público durante a vigência do Código de Processo Civil de 1973 (CPC/73). O primeiro óbice era a obrigatoriedade de aplicação do instituto do reexame necessário, constante do art. $475, \mathrm{CPC} / 73$. O segundo cuidava da necessidade de observância do regime de precatórios, segundo a sistemática do art. 100, CF/88, para que se pudesse operacionalizar o recebimento de valores advindos da Fazenda Pública.

Pouco tempo depois, em 13 fevereiro de 1998, o STF concluiu, no julgamento da Medida Cautelar (MC) na Ação Direta de Constitucionalidade (ADC) no 04/DF, que, em princípio, não eram inconstitucionais as vedações à concessão de liminares contra o Poder Público 9 .

Logo após este pronunciamento do STF, parte dos magistrados entendeu pela vedação irrestrita de tais concessões ${ }^{10}$, mas, com o passar do tempo, prevaleceu a corrente

\footnotetext{
${ }^{7}$ MARINONI, Luiz Guilherme; MITIDIERO, Daniel. Direito fundamental à tutela adequada e efetiva. In: SARLET, I. W.; MARINONI, L. G.; MITIDIERO, D. Curso de Direito Constitucional. $8^{a}$ ed. São Paulo: Saraiva Educação, 2019. Cap. 5.3, p. 832; BUENO, Cássio Scarpinella. Novo Código de Processo Civil Anotado. $3^{\text {a }}$ ed. São Paulo: Saraiva, 2017, p. 1016; MILLER, Cristiano Simão. Art. 1.059. In: ALVIM, A. A., et al. Comentários ao Código de Processo Civil - Lei n. 13.105/2015. 2a ed. São Paulo: Saraiva, 2017. p. 1259; CAIS, Cleide Previtalli. O processo tributário. $8^{\text {a }}$ ed. São Paulo: Revista dos Tribunais, 2013, p. 418; MARINS, James. Direito Processual Tributário Brasileiro - Administrativo e Judicial. 12a ed. São Paulo: Thomson Reuters Brasil, 2019, p. 668; LOPES, João Batista. Tutela antecipada no processo civil brasileiro. $3^{\mathrm{a}}$. ed. São Paulo: Editora Revista dos Tribunais, 2007, p. 115; VEIGA, Daniel Brajal, et al. Tutela provisória: questões polêmicas. In: BUENO, C. S., et al. Tutela Provisória no CPC: dos 20 anos de vigência do art. 273 do CPC/73 ao CPC/2015. 2a ed., Cap. 24, São Paulo: Saraiva Educação, 2018, p. 557-562.

${ }^{8}$ STF, Pleno, MC na ADI $n^{\circ}$ 1.576/DF, Rel. Min. Marco Aurélio, j. 16 abr. 1997. DJ 06 jun. 2003, p. 131-133.

${ }^{9}$ STF, Pleno, $A D C n^{o}$ 04/DF, Rel. Min. Sydney Sanches. Rel. p/ Acórdão Min. Celso de Mello, j. 01 out. 2008. DJe 30 out. 2014.

${ }^{10}$ STJ, $1^{\text {a }}$ Turma, REsp n ${ }^{\circ}$ 188.974/MS, Rel. Min. Garcia Vieira, j. 04 mar. 1999. DJ 03 mai. 1999.
} 
que entendia pela possibilidade de concessão das tutelas em hipóteses nas quais a denegação do pedido implicaria em ameaça à própria sobrevivência do demandante ${ }^{11}$.

Nos anos que se seguiram, os tribunais superiores passaram, então, a se debruçar de maneira cada vez mais detida sobre os tais óbices doutrinários à utilização de tutelas provisórias contra a Fazenda Pública.

\subsection{O óbice do duplo grau de jurisdição necessário}

Quanto ao primeiro óbice, o instituto da remessa necessária, também chamada de reexame necessário, nada mais é do que o envio obrigatório de sentença para o segundo grau de jurisdição, nos casos previstos em lei, dentre os quais estão as sentenças proferidas em interesse contrário ao da Fazenda Pública. Sentenças contra o Poder Público, portanto, seriam sentenças de eficácia condicionada ao duplo grau de jurisdição ${ }^{12}$.

O contexto em voga, à época do CPC/73, era de que a tutela antecipada, por cuidar, em tese, de adiantamento de sentença, necessitaria de confirmação pelo Tribunal, conforme o art. 475, do Código de Processo vigente. Este dispositivo declarava que a sentença contra a Fazenda Pública só seria eficaz depois de confirmação pelo segundo grau de jurisdição, em homenagem à ideia de plenitude do processo, de modo que uma tutela antecipada contra o Poder Público, por sua própria natureza, seria ineficaz ${ }^{13}$.

Hugo de Brito Machado Segundo, por sua vez, entende que as tutelas provisórias têm fundamento constitucional no princípio da inafastabilidade da tutela jurisdicional (art. $5^{\circ}, \mathrm{XXXV}, \mathrm{CF} / 88$ ) e que, portanto, seu deferimento ou não, dependeria exclusivamente do cotejo desse princípio com outro, que é o que assegura o direito do demandado a um processo pleno, fundamentado na formalidade e na segurança processuais ${ }^{14}$.

Tal plenitude de jurisdição, por certo, no entanto, diminui o grau de celeridade necessário para a adequada satisfação do acesso à Justiça, visto que "as relações econômicas e pessoais da atualidade não se compatibilizam com a longa espera de decisões finais na

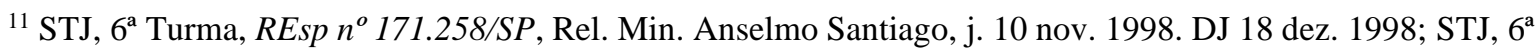
Turma, REsp $n^{\circ}$ 463.778/RS, Rel. Min. Vicente Leal, j. 26 nov. 2002. DJ 19 dez. 2002.

${ }^{12}$ BUENO, Cássio Scarpinella. Liminar em mandado de segurança: um tema com variações. $2^{\mathrm{a}}$ ed. São Paulo: Editora Revista dos Tribunais, 1999, p. 38.

${ }^{13}$ NUNES, Cleucio Santos. Curso Completo De Direito Processual Tributário. $2^{\text {a }}$ Ed. São Paulo: Saraiva Educação., 2018, p. 498.

${ }^{14}$ MACHADO SEGUNDO, Hugo de Brito. Processo Tributário. 10 a ed. São Paulo: Atlas, 2018, p. 480.
} 
Justiça" ${ }^{15}$. Dentro dessa percepção parte da doutrina acreditava que, mesmo na vigência do CPC/73, seria possível deferir a tutela antecipada contra a Fazenda Pública em razão do princípio da efetividade do processo ${ }^{16}$.

O escopo fundamental desta efetividade seria o grau de predisposição do processo para gerar efeitos concretos na vida dos jurisdicionados. Assim, o processo efetivo seria aquele que produz efeitos na vida das pessoas, efetivamente eliminando a lide ${ }^{17}$.

Nesse sentido, Cássio Scarpinella Bueno aponta que tal efetividade seria "o moto perpetuo da antecipação de tutela", devendo ser mitigadas as características de cognição exauriente e de máxima segurança jurídica do processo, ambas calcadas na sentença judicial transitada em julgado ${ }^{18}$. De fato, a própria incorporação do instituto da antecipação de tutela ao ordenamento jurídico brasileiro, por meio da Lei $n^{\circ} 8.952 / 94$, pode ser entendida como um sinal de que o legislador estaria prestigiando - mesmo nos casos do art. 475, I e II, CPC/73 - a efetividade da Justiça, em detrimento da segurança jurídica do processo pleno e exauriente, cujo ato culminante é a sentença ${ }^{19}$.

Essencialmente, são quatro as razões que determinam o afastamento do óbice doutrinário do reexame necessário ao cabimento das tutelas provisórias - e de quaisquer outras medidas liminares - contra a Fazenda Pública.

A primeira razão é de que a Lei $n^{\circ} 8.952 / 94$, responsável pela positivação da antecipação de tutela no CPC/73, ao alterar a redação dos arts. 273 e 461, CPC/73, "não teria vedado o deferimento da medida contra a Fazenda Pública, descabendo à doutrina criar restrição não prevista em lei" ${ }^{20}$. Com efeito, na Rcl n ${ }^{\circ} 1.514 / \mathrm{RS}$, apontou-se que,

\footnotetext{
${ }^{15}$ NUNES, Cleucio Santos. Curso Completo De Direito Processual Tributário. $2^{\mathrm{a}}$ Ed. São Paulo: Saraiva Educação., 2018, p. 499-500.

${ }^{16}$ BUENO, Cássio Scarpinella. Liminar em mandado de segurança: um tema com variações. $2^{\text {a }}$ ed. São Paulo: Editora Revista dos Tribunais, 1999, p. 49.

${ }^{17}$ DIAS, Jean Carlos. Tutelas provisórias no novo CPC: tutelas de urgência: tutela de evidência. $2^{\mathrm{a}}$ ed. Salvador: Juspodivm, 2018, p. 37-38.

${ }^{18}$ BUENO, Cássio Scarpinella. Liminar em mandado de segurança: um tema com variações. $2^{\text {a }}$ ed. São Paulo: Editora Revista dos Tribunais, 1999, p. 38.

${ }^{19}$ Nesse sentido, "vê-se inegavelmente, a partir da força e do reconhecimento à tutela de urgência antecipatória, que a intenção do direito processual civil atual é sacrificar o valor da segurança ao da efetividade. Interpretar essas mudanças com base em corolários jurídicos de antanho (apegados à segurança) é antes negar valor ao progresso natural do ser humano" (ALVES, Francisco Glauber Pessoa. A tutela antecipada em face da Fazenda Pública, seu perfil contemporâneo (tendências jurisprudenciais) e a necessidade de uma hermenêutica que lhe atribua efetividade. Revista de Processo, São Paulo: ano 28, n. 110, p. 37 a 71, 2003, p. 62).

${ }^{20}$ NUNES, Cleucio Santos. Curso Completo De Direito Processual Tributário. $2^{\mathrm{a}}$ Ed. São Paulo: Saraiva Educação., 2018, p. 500.
} 


\begin{abstract}
uma vez atendidos os pressupostos legais fixados no art. 273, I e II, do CPC, na redação dada pela Lei $n^{\circ}$ 8.952/94 - e observadas as restrições estabelecidas na Lei $n^{\circ}$ 9.494/97 (art. $1^{\circ}$ ) -, tornar-se-á lícito ao magistrado deferir a tutela antecipatória requerida contra a Fazenda Pública. Isso significa, portanto, que Juízes e Tribunais - sem incorrerem em desrespeito à eficácia vinculante decorrente do julgamento proferido pelo Supremo Tribunal Federal na apreciação do pedido de medida cautelar formulado na ADC 4-DF, Rel. Min, SYDNEY SANCHES - poderão antecipar os efeitos da tutela jurisdicional em face do Poder Público, desde que o provimento de antecipação não incida em qualquer das situações de pré-exclusão referidas, taxativamente, no art. $1^{\circ}$ da Lei n ${ }^{\circ}$ 9.494/97. (STF, Decisão Monocrática, Rcl $n^{\circ}$ 1.514/RS, Rel. Min. Celso de Mello, j. 05 jun. 2000. DJ 19 jun. 2000, p. 1)
\end{abstract}

No mesmo sentido, no REsp $\mathrm{n}^{\circ}$ 638.919/RS, restou consignado que a própria existência do art. $1^{\circ}$, Lei n ${ }^{\circ}$ 9.494/97 reforçava a interpretação de que a impossibilidade de concessão de tutela antecipada contra o Poder Público deveria se verificar somente nas hipóteses taxativamente previstas. A regra, portanto, seria a possibilidade de concessão ${ }^{21}$.

A segunda razão é de que a decisão que defere a antecipação tem natureza interlocutória, "sendo dotada de provisoriedade e passível de modificação ou de revogação pelo próprio juízo que a concede" 22 . Assim, não haveria que se falar em eficácia condicionada, pois não se trataria de sentença, posto que não há extinção do processo $^{23}$. Em face da efetividade do processo, portanto, a interpretação do art. 475, CPC/73, nunca deveria se dar de forma a mitigar os próprios objetivos da antecipação tutela, mesmo quando o Poder Público for parte da lide ${ }^{24}$.

A terceira razão advém de duas das alterações, propostas pela Lei $\mathrm{n}^{\circ}$ 10.352/2001, ao art. 475, CPC/73. A primeira alteração foi o acréscimo do art. 475, §2, $\mathrm{CPC} / 73$, que excluía da remessa necessária as condenações judiciais de valor não superior a 60 (sessenta) salários mínimos. Para valores abaixo desse limite, portanto, a tutela antecipada seria perfeitamente cabível. A segunda alteração foi a adição do art. $475, \S 3^{\circ}, \mathrm{CPC} / 73$, que excluiu da remessa necessária os casos em que o fundamento da concessão de antecipação fosse súmula de tribunal superior. A própria existência destas duas alterações demonstra que o duplo grau de jurisdição nunca fora incompatível com a tutela antecipada ${ }^{25}$.

\footnotetext{
${ }^{21}$ STJ, $5^{\text {a }}$ Turma, REsp $n^{o}$ 638.919/RS, Rel. Min. Felix Fischer, j. 23 jun. 2004, DJ 09 ago. 2004.

${ }^{22}$ CAIS, Cleide Previtalli. O processo tributário. $8^{\text {a }}$ ed. São Paulo: Revista dos Tribunais, 2013, p. 433.

${ }^{23}$ BUENO, Cássio Scarpinella. Liminar em mandado de segurança: um tema com variações. $2^{a}$ ed. São Paulo: Editora Revista dos Tribunais, 1999, p. 38.

${ }^{24}$ Como exemplo, cita-se STJ, 6 ${ }^{\mathrm{a}}$ Turma, REsp $n^{\circ}$ 659.200/DF, Rel. Min. Hélio Quaglia Barbosa, j. 21 set. 2004. DJ 11 out. 2004.

${ }^{25}$ NUNES, Cleucio Santos. Curso Completo De Direito Processual Tributário. $2^{\text {a }}$ Ed. São Paulo: Saraiva Educação., 2018, p. 504.
} 
Assim, da mesma forma que a inclusão de dispositivo legal que restringe a concessão de tutela antecipada autoriza a compreensão de que tal tutela é cabível nos casos não previstos, a inclusão de dispositivos autorizadores da concessão - como é o caso do art. $475, \S \S 2^{\circ}$ e $3^{\circ}, \mathrm{CPC} / 73$ - também autoriza a interpretação de que, de fato, a tutela antecipada (e, por conseguinte, todo e qualquer provimento liminar fundado em urgência) não é incompatível com a remessa necessária. Este argumento também encontra guarida nos tribunais pátrios, como se denota do REsp n $n^{\circ} 1.085 .257 / \mathrm{SP}$, cuja centralidade reside no princípio da efetividade da tutela jurisdicional ${ }^{26}$. Neste julgado, cita-se, adicionalmente, a previsão do art. 13, Lei $\mathrm{n}^{\circ}$ 10.259/2001, que dispensa o reexame necessário nas causas de competência do Juizado Especial Federal (JEF) ${ }^{27}$.

A quarta razão, por sua vez, se trata de argumento de ordem material, fundado no princípio da isonomia (art. $5^{\circ}$, caput, $\mathrm{CF} / 88$ ). Leonardo Martins aponta que, ao se verificar possível violação do direito à igualdade, deve-se questionar o seu motivo, visto que, ao Estado, seria "lícito criar desigualdades sempre que elas não restarem arbitrárias ou não forem destituídas de fundamento racional"28.

Nesse sentido, para Hugo de Brito Machado Segundo, a Fazenda Pública, por ser distinta dos cidadãos em geral, de fato merece tratamento diferenciado, contudo, excessivo alargamento concedido pela legislação a essa distinção poderia resultar em abusos e privilégios injustificados ${ }^{29}$.

Com efeito, sabendo-se que, quando a Fazenda é autora, a antecipação pode ser concedida contra os administrados, não haveria razão para o contrário também não ser verdadeiro. De fato, "ainda que a lei processual restringisse a antecipação dos efeitos da tutela quando a parte contrária fosse a Fazenda, haveria inegável ofensa ao princípio da isonomia e ao estado de direito" $"$.

\footnotetext{
${ }^{26}$ STJ, $2^{\mathrm{a}}$ Turma, REsp $n^{\circ}$ 1.085.257/SP, Rel. Min. Eliana Calmon, j. 09 dez. 2008. DJe 24 mar. 2009.

${ }^{27}$ No mesmo sentido, ALVES, Francisco Glauber Pessoa. A tutela antecipada em face da Fazenda Pública, seu perfil contemporâneo (tendências jurisprudenciais) e a necessidade de uma hermenêutica que lhe atribua efetividade. Revista de Processo, São Paulo: ano 28, n. 110, p. 37 a 71, 2003, p. 63.

${ }^{28}$ MARTINS, Leonardo. Direito Fundamental à Igualdade. In: CANOTILHO, J. J. G., et al. Comentários à Constituição do Brasil. 2. ed. São Paulo: Saraiva Educação, 2018, p. 231.

${ }^{29}$ MACHAdO SEGUNDO, Hugo de Brito. Processo Tributário. 10 a ed. São Paulo: Atlas, 2018, p. 21.

${ }^{30}$ NUNES, Cleucio Santos. Curso Completo De Direito Processual Tributário. $2^{\mathrm{a}}$ Ed. São Paulo: Saraiva Educação., 2018, p. 500.
} 


\subsection{O óbice do regime de precatórios}

O segundo óbice à concessão de tutelas provisórias contra a Fazenda Pública, como apontado pela doutrina, era a existência do regime de precatórios, disciplinado pelo art. 100, $\mathrm{CF} / 88$. Vale ressaltar que esse sistema sofreu diversas mudanças ao longo do tempo, por ação do Poder Constituinte Derivado (EC n 20/1998, EC n 30/2000, EC no 37/2002, EC nº 62/2009 e EC no 94/2016), bem como por efeito de decisões judiciais, cujos mais significativos exemplos são a $\mathrm{ADI} \mathrm{n}^{\circ} 2.356 / \mathrm{DF}^{31}$, a $\mathrm{ADI} \mathrm{n}^{\mathrm{o}} 4.425 / \mathrm{DF}^{32}$ e a $\mathrm{ADI} \mathrm{n}^{\mathrm{o}}$ 4.357/DF ${ }^{33}$.

Essencialmente, o sistema de precatórios permite à Fazenda que pague seus débitos - desde que não seja caso de cabimento de Requisição de Pequeno Valor (RPV), nos termos do art. $100, \S 3^{\circ}, \mathrm{CF} / 88$ - até o final do exercício financeiro seguinte à inscrição precatório no orçamento público. No julgamento da MC na ADI n ${ }^{\circ}$ 2.356/DF, o STF asseverou que este sistema tem, ao mesmo tempo, status de prerrogativa processual do Poder Público e de garantia constitucional de cumprimento de decisão judicial contra a Fazenda Pública, "que se define em regras de natureza processual conducentes à efetividade da sentença condenatória trânsita em julgado por quantia certa contra entidades de direito público" ${ }^{34}$.

A razão para que se entenda o referido sistema como obstáculo à concessão de liminares nos casos em que a tutela consistir em pagamento de valores pelo Poder Público seria de que ele impõe regras especiais para execução. De acordo com este entendimento, o credor deve (i) aguardar o trânsito em julgado da sentença condenatória e (ii) obedecer a um regime cronológico de precatórios. Estas regras, portanto, não se coadunariam, a princípio, com a tutela antecipada, que pressupõe celeridade de execução ${ }^{35}$.

Adicionalmente, ainda haveria o problema de que, no modelo tradicional de processo, a execução judicial dependeria de título executivo, seja ele judicial ou extrajudicial, dentro da ideia de nulla executio sine titulo (livremente traduzida como é nula

\footnotetext{
${ }^{31}$ STF, Pleno, MC na ADI $n^{\circ}$ 2.356/DF, Rel. Min. Néri da Silveira, Rel. p/ Acórdão Min. Ayres Britto, j. 25 nov. 2010. DJe 19 mai. 2011.

${ }^{32}$ STF, Pleno, $A D I n^{\circ}$ 4.425/DF, Rel. Min. Ayres Britto, Rel. p/ Acórdão: Min. Luiz Fux, j. 14 mar. 2013. DJe 19 dez. 2013.

${ }^{33}$ STF, Pleno, ADI $n^{o}$ 4.357/DF, Rel. Min. Ayres Britto. Rel. p/ Acórdão Min. Luiz Fux, j. 14 mar. 2013. DJe 26 set. 2014.

${ }^{34}$ STF, Pleno, MC na ADI $n^{o}$ 2.356/DF, Rel. Min. Néri da Silveira, Rel. p/ Acórdão Min. Ayres Britto, j. 25 nov. 2010. DJe 19 mai. 2011, p. 153.

${ }^{35}$ NUNES, Cleucio Santos. Curso Completo De Direito Processual Tributário. 2 ${ }^{\mathrm{a}}$ Ed. São Paulo: Saraiva Educação., 2018, p. 498-499.
} 
execução sem título). Nesse sentido, parte da doutrina defendia que a antecipação de tutela se assemelhava à execução sem título, visto que a decisão interlocutória que a defere não conteria, em si, direito já declarado ou do qual já não haveria mais possibilidade de recurso, ou seja, da qual não se teria verificado o trânsito em julgado ${ }^{36}$.

Em contraponto, outro segmento da doutrina entende que o sistema de precatórios não constitui óbice à concessão de tutela antecipada contra a Fazenda Pública. Mesmo na vigência do $\mathrm{CPC} / 73$, já se observava que a significativa lentidão das execuções contra o Estado constituía verdadeiro empecilho para a concretização de direito reconhecido judicialmente, em prol do particular. Em razão disso, deveria ser cabível a antecipação de tutela contra o Poder Público, desde que, por certo, (i) ficassem demonstrados os pressupostos de perigo na demora e verossimilhança da alegação, e (ii) o juízo da execução provisória ficasse convencido de que a efetivação do direito do beneficiário da tutela antecipada não acarretaria a irreversibilidade da decisão ${ }^{37}$.

Modernamente, o entendimento pela possibilidade da concessão de liminares contra o Poder Público é sustentado por quatro razões principais, em especial no campo tributário. A primeira, de cunho eminentemente prático, é de que, concedida a liminar, caso esta não se confirme em sede de provimento final, o contribuinte arcará com as penalidades pecuniárias advindas da mora a partir do momento em que a tutela provisória tenha sido indevidamente concedida, de modo que a Fazenda Pública, efetivamente, não terá prejuízos concretos ${ }^{38}$.

A segunda razão enfrenta a questão de a execução judicial, a princípio, depender de título executivo. Nesse sentido, entende-se que a tutela antecipatória rompe com o princípio da nulla executio sine titulo, visto que

as novas exigências de tutela jurisdicional célere e pronta - responsáveis,
inclusive, pela transformação da tutela cautelar em técnica de sumarização do
processo de conhecimento - transformaram o princípio da nulla executio sine
titulo em mito. Em outros termos: os novos conflitos, por sua própria natureza,
deixaram clara a necessidade de tutela antecipatória, ou seja, realização do direito
no curso do processo de conhecimento. Nesse caso, passou-se a admitir a tutela do
direito antes da realização plena do contraditório. Para a efetividade da tutela do
direito, restringe-se, em um primeiro momento, o direito à produção de provas, o
qual mais tarde pode ser exercido de forma integral no mesmo processo em que a

36 MARINONI, Luiz Guilherme; ARENHART, Sérgio Cruz. Curso de Processo Civil: Processo de Conhecimento. 12a ed. São Paulo: Revista dos Tribunais, v. 2, 2014, p. 205.

${ }^{37}$ BUENO, Cássio Scarpinella. Liminar em mandado de segurança: um tema com variações. $2^{\mathrm{a}}$ ed. São Paulo: Editora Revista dos Tribunais, 1999, p. 48-51.

${ }^{38}$ NUNES, Cleucio Santos. Curso Completo De Direito Processual Tributário. $2^{\text {a }}$ Ed. São Paulo: Saraiva Educação., 2018, p. 501. 
tutela antecipatória é concedida, garantindo-se, dessa forma e apenas com um processo, o direito à efetividade da tutela jurisdicional e o direito ao contraditório (que na hipótese é apenas postecipado) ${ }^{39}$

No mesmo sentido desta nova tendência do Processo Civil, vale ressaltar que o STF, no RE $n^{\circ} 573.872 / R S$, fixou o Tema $n^{\circ} 45$ da Repercussão Geral ${ }^{40}$, no qual entendeu ser possível execução provisória de qualquer decisão (excetuando-se aquelas em que se verifica obrigação de pagar quantia certa), mesmo na pendência de recursos, desde que estes não tenham sido recebidos com efeito suspensivo. Verifica-se, assim, na prática, a presente tendência da jurisprudência em mitigar a ideia da nulla executio sine titulo ${ }^{41}$.

Este mesmo julgado remete, adicionalmente, à terceira razão, consubstanciada no fato de que o regime de precatórios não é aplicável a todas as formas de cumprimento de sentenças contra a Fazenda Pública. Isso porque restou consignado que as obrigações de fato positivo ou negativo não atraem a aplicação do art. 100, CF/88 ${ }^{42}$.

Outro exemplo seria a autocompensação tributária, na qual o contribuinte pode compensar o crédito decorrente do pagamento indevido com tributos vincendos, em operação contábil realizada em seus próprios registros. De fato, partindo-se da ideia de que há uma diferença entre "pagamento" e "escrituração contábil" (esta última também chamada de "acertamento contábil"), em princípio não haveria empecilhos à concessão de tutela antecipada, visto que não se trata de pagamento e, portanto, não há que se falar em aplicação do art. $100, \mathrm{CF} / 88^{43}$.

Vantagem adicional que a concessão de tutela provisória contra Fazenda Pública traria para os casos concretos seria a instrumentalização da execução. Isso se daria porque a concessão da tutela forçaria o Juízo, desde logo, a quantificar o bem perseguido pelo autor

\footnotetext{
39 MARINONI, Luiz Guilherme; ARENHART, Sérgio Cruz. Curso de Processo Civil: Processo de Conhecimento. 12a ed. São Paulo: Revista dos Tribunais, v. 2, 2014, p. 206.

${ }^{40} \mathrm{STF}$, Pleno, $R E n^{\circ}$ 573.872/RS, Rel. Min. Edson Fachin, j. 24 mai. 2017. DJe 11 set. 2017.

${ }^{41} \mathrm{O}$ resultado prático dessa nova tendência também gera efeitos sobre as ações de repetição de indébito tributário. De fato, o rompimento com o princípio da nulla executio sine titulo permite a constatação de que, nos casos em que a motivação para restituição de indébito tributário residir no reconhecimento de que o tributo é indevido em face de decisão erga omnes do STF (ou seja, quando estiver dotada de alto grau de probabilidade), o art. 100, CF/88, sequer se aplicaria, visto que a antecipação dos efeitos da tutela obedece à lógica da execução sem título, em especial por não haver dúvidas sobre o recolhimento indevido dos valores (NUNES, Cleucio Santos. Curso Completo De Direito Processual Tributário. 2a Ed. São Paulo: Saraiva Educação., 2018, p. 505).

${ }^{42}$ STF, Pleno, $R E n^{o}$ 573.872/RS, Rel. Min. Edson Fachin, j. 24 mai. 2017. DJe 11 set. 2017.

${ }^{43}$ NUNES, Cleucio Santos. Curso Completo De Direito Processual Tributário. $2^{\text {a }}$ Ed. São Paulo: Saraiva Educação., 2018, p. 501-502.
} 
da ação, o que facilitaria a expedição do precatório e seu depósito no exercício orçamentário seguinte, onde poderia ficar até o julgamento final do feito ${ }^{44}$.

Adicionalmente, frente à natureza interlocutória das decisões de concessão de tutela antecipada, Francisco Glauber Pessoa Alves entende que a concessão destas tutelas não inviabilizaria o equilíbrio orçamentário, já que, da mesma maneira que o orçamento faz uma previsão para sentenças de mérito, poderia, também, fazer para as decisões interlocutórias ${ }^{45}$.

A quarta e última razão para o afastamento do óbice do regime de precatórios à concessão de tutelas provisórias contra a Fazenda Pública é o próprio advento da LC $\mathrm{n}^{\mathrm{o}}$ 104/2001, que acrescentou o inciso V ao art. 151, CTN, incluindo a tutela antecipada como causa de suspensão da exigibilidade do crédito tributário ${ }^{46}$.

Feita esta inclusão, já não restaram mais dúvidas de que a concessão do instituto da tutela antecipada sempre foi possível em matéria tributária, mesmo em face dos óbices impostos pela doutrina e sumarizados na ADI $n^{\circ}$ 1.576/DF e na $\mathrm{ADC}^{\circ}$ 04/DF. De fato, o próprio STJ assim entendeu, no REsp no 716.379/RN, justamente com base na redação do art. $151, \mathrm{~V}, \mathrm{CTN}^{47}$.

Paralelamente, com o julgamento do REsp $n^{\circ} 853.880 / R S$, se reconheceu que o sistema de precatórios não se aplica às obrigações definidas em lei como de pequeno valor, visto que estas são pagas por meio de RPV, na forma do art. 100, $\S 3^{\circ}, \mathrm{CF} / 88$. Vale ressaltar que, nesta ocasião, o relator, Min. Castro Meira, prestou significativa homenagem ao poder geral de cautela do juiz, reforçando que o rol do art. 461, $\S 5^{\circ}, \mathrm{CPC} / 73$, é meramente enumerativo e que o magistrado deve escolher as medidas assecuratórias que melhor garantam a efetividade da tutela no caso concreto. Apontou, também, que "submeter os provimentos deferidos em antecipação dos efeitos da tutela ao regime de precatórios seria o mesmo que negar a possibilidade de tutela antecipada contra a Fazenda Pública” ${ }^{48}$.

\footnotetext{
${ }^{44}$ BUENO, Cássio Scarpinella. Liminar em mandado de segurança: um tema com variações. $2^{\mathrm{a}}$ ed. São Paulo: Editora Revista dos Tribunais, 1999, p. 49.

45 ALVES, Francisco Glauber Pessoa. A tutela antecipada em face da Fazenda Pública, seu perfil contemporâneo (tendências jurisprudenciais) e a necessidade de uma hermenêutica que lhe atribua efetividade. Revista de Processo, São Paulo: ano 28, n. 110, p. 37 a 71, 2003, p. 69.

46 NUNES, Cleucio Santos. Curso Completo De Direito Processual Tributário. $2^{\text {a }}$ Ed. São Paulo: Saraiva Educação., 2018, p. 504.

${ }^{47}$ STJ, $2^{\text {a }}$ Turma, REsp $n^{o}$ 716.379/RN, Rel. Min. Franciulli Netto, j. 03 mar. 2005, DJ 22 ago. 2005.

${ }^{48}$ STJ, $2^{\text {a }}$ Turma, REsp $n^{o} 853.880 / R S$, Rel. Min. Castro Meira, j. 19 set. 2006. DJ 28 set. 2006, p. 5.
} 
Este entendimento, cada vez mais sólido no STJ, passou a ser utilizado, também, para permitir o bloqueio de verbas públicas, como medida assecuratória atípica fundada no poder geral de cautela do juiz, sedimentando o afastamento do óbice do regime de precatórios à concessão de tutelas provisórias contra o Poder Público, como exemplificado no AgR no REsp n ${ }^{\circ}$ 935.083/RS ${ }^{49}$.

\section{A SUPOSTA INCOMPATIBILIDADE DA AÇÃO DE REPETIÇÃO DE INDÉBITO TRIBUTÁRIO COM AS TUTELAS PROVISÓRIAS}

Restando estabelecido que a concessão de tutelas provisórias sempre foi possível em matéria tributária, mesmo em face dos obstáculos impostos pela doutrina e sumarizados na $\mathrm{ADI} \mathrm{n}^{\circ} 1.576 / \mathrm{DF}$ e na $\mathrm{ADC} \mathrm{n}^{\circ} 04 / \mathrm{DF}$, passa-se a examinar, com maior detalhamento, seu cabimento na situação específica das ações tributárias de repetição de indébito.

As normas gerais para o pleito de repetição de indébito estão descritas nos art. 165 a 169, CTN. De fato, da leitura do art. 165, caput, CTN, pode-se definir a repetição de valores como uma obrigação jurídico-fiscal do Poder Público em devolver ao contribuinte, "de forma ampla e integral e mediante mecanismos céleres e econômicos, todo e qualquer valor recolhido indevidamente aos cofres públicos, no âmbito de sua relação tributária"50.

Também é de se ressaltar que o direito à restituição tem relação com os princípios da supremacia da força normativa da Constituição e da segurança jurídica, visto que "se o Estado mantém em seus cofres tributo em montante superior ao valor que o ordenamento jurídico lhe autoriza, torna-se obrigatória a imediata restauração da ordem jurídica" $" 51$.

Isto posto, a ação de repetição de indébito tributário, também chamada de ação de restituição de valores ou ação de repetição do indébito, é um tipo de ação tributária que pressupõe certeza e liquidez dos valores supostamente recebidos de maneira indevida pela Fazenda Pública. Adicionalmente, de acordo com a corrente mais tradicional da doutrina, a certeza e a liquidez do crédito tributário estariam conectadas ao trânsito em julgado da decisão condenatória ${ }^{52}$.

Nesse sentido, dentre outras prerrogativas concedidas às pessoas jurídicas de direito públicos federais, estaduais e municipais, a Medida Provisória (MP) n ${ }^{\circ}$ 1.798-1/99

\footnotetext{
${ }^{49}$ STJ, $2^{\text {a }}$ Turma, AgRg no REsp no 935.083/RS, Rel. Min. Humberto Martins, j. 02 ago. 2007. DJ 15 ago. 2007.

${ }^{50}$ MARINS, James. Direito Processual Tributário Brasileiro - Administrativo e Judicial. $12^{\mathrm{a}}$ ed. São Paulo: Thomson Reuters Brasil, 2019, p. 336-337.

${ }^{51}$ CAIS, Cleide Previtalli. O processo tributário. $8^{\text {a }}$ ed. São Paulo: Revista dos Tribunais, 2013, p. 409.

${ }^{52}$ NUNES, Cleucio Santos. Curso Completo De Direito Processual Tributário. $2^{\mathrm{a}}$ Ed. São Paulo: Saraiva Educação., 2018, p. 505.
} 
(posteriormente confirmada pela MP $\mathrm{n}^{\circ} 2.180-35 / 2001$ ), por meio de seu art. $5^{\circ}$, adicionou o art. $2^{\circ}$-B à Lei $n^{\circ}$ 9.494/97. Este dispositivo aponta que sentenças que impliquem em "liberação de recurso, inclusão em folha de pagamento, reclassificação, equiparação, concessão de aumento ou extensão de vantagens a servidores" somente poderiam ser executadas após seu trânsito em julgado.

No mesmo sentido é a previsão do art. 1.059, CPC/2015, quando combinada com a última parte do art. $7^{\circ}, \S 2^{\circ}$, Lei $n^{\circ} 12.016 / 2009$, que determinam que não serão concedidas tutelas provisórias contra o Poder Público quando seu deferimento resultar em concessão de aumento ou a extensão de vantagens ou pagamento de qualquer natureza. Tais dispositivos ecoam, por certo, os óbices doutrinários do reexame necessário e do regime de precatórios.

A incompatibilidade em questão se daria porque, sob uma perspectiva orçamentária, os recursos que deveriam ser restituídos não constariam, necessariamente, do orçamento da Fazenda. Assim, se a restituição de valores for entendida como uma "liberação de recursos" ou como um "pagamento de qualquer natureza", estaria ela condicionada ao trânsito em julgado, tornando incompatível esta ação com o instituto da tutela provisória. Isto posto, tal prerrogativa do Poder Público é uma entre as duas principais razões para que se defenda o descabimento do instituto da tutela provisória nas repetições de indébito tributário. A segunda razão, por sua vez, seria a própria jurisprudência dominante ${ }^{53}$.

De fato, no AgRg no REsp no 221.014/PE, entendeu-se que estaria solidificado, nas Turmas de Direito Público do STJ, o entendimento de que não é permitido o deferimento de repetição de indébito e de compensação, "via liminar em mandado de segurança ou em ação cautelar, ou em qualquer tipo de provimento que antecipe a tutela da ação"54.

Da mesma forma, nos Embargos de Declaração (EDcl) em Apelação Cível $n^{\circ}$ 0021402-72.2004.4.05.8100/02, apreciados pela Segunda Turma do Tribunal Regional Federal da $5^{\mathrm{a}}$ Região (TRF-5), restou consignado que "o pedido de repetição de indébito tributário não comporta deferimento de tutela antecipada, nos mesmos moldes da compensação (art. 170-A do CTN e Súmula 212 do STJ)", de modo que a execução de

\footnotetext{
${ }^{53}$ NUNES, Cleucio Santos. Curso Completo De Direito Processual Tributário. $2^{\mathrm{a}}$ Ed. São Paulo: Saraiva Educação., 2018, p. 505-508.

${ }^{54}$ STJ, $1^{\text {a }}$ Turma, AgRg no REsp no 221.014/PE, Rel. Min. José Delgado, j.05 out. 1999. DJ 29 nov. 1999, p.2.
} 
condenação à repetição de indébito tributário só poderia ocorrer após o efetivo trânsito em julgado da sentença condenatória ${ }^{55}$.

Vale ressaltar, no entanto, o julgamento do REsp no 148.072/RJ, pela Primeira Turma do STJ. Na ocasião, ainda no ano de 1997, apesar de ter sido negado deferimento de tutela antecipada contra a Fazenda Pública, de acordo com o entendimento predominante, entendeu-se que, no campo tributário, tal vedação poderia ser afastada. Isso se daria nos casos em que houvesse entendimento jurisprudencial uniformizado sobre a relação jurídica em debate ${ }^{56}$. A partir deste julgado, abre-se relevante corrente de discussão, a ser retomada mais adiante, acerca da possibilidade de deferimento de tutelas de evidência contra a Fazenda Pública com fundamento no art. 311, II, CPC/2015, ou seja, quando o argumento do autor estiver fundado em teses repetitivas dos tribunais superiores.

\section{O FUNDAMENTO CONSTITUCIONAL DO DIREITO À REPETIÇÃO DE INDÉBITO E A SUPERAÇÃO DOS OBSTÁCULOS À CONCESSÃO DE TUTELAS PROVISÓRIAS}

Para parte da doutrina, a constitucionalidade do art. $2^{\circ}$-B, Lei $n^{\circ}$ 9.494/1997 e do

art. 1.059, CPC/2015, é questionável, de modo que o argumento pelo descabimento das tutelas provisórias nas ações de repetição de indébito tributário também deve ser discutido em sede de controle de constitucionalidade ${ }^{57}$. O controle de constitucionalidade se trata, essencialmente, de um mecanismo de correção, destinado a reestabelecer a harmonia de um sistema constitucional, por meio da "verificação da compatibilidade entre uma lei ou qualquer ato normativo infraconstitucional e a Constituição"58.

O mecanismo do controle de constitucionalidade opera por meio da relação entre norma-parâmetro e norma-objeto. As normas-objeto são as que se deseja aferir a constitucionalidade - no caso em tela, o art. $2^{\circ}$-B, da Lei $n^{\circ}$ 9.494/1997 e o art. 1.059, CPC/2015. A norma-parâmetro, por sua vez, é uma norma de hierarquia superior, à qual a norma-objeto deve estar subordinada, formal, procedimental e substancialmente, e que pode se manifestar, também, sob a forma de um "bloco de constitucionalidade", de modo que o

\footnotetext{
55 TRF-5, $2^{\mathrm{a}}$ Turma, EDcl em Apelação Cível $n^{\circ}$ 0021402-72.2004.4.05.8100/02, Rel. Des. Francisco Barros Dias, j. 28 abr. 2009. DJ 20 mai. 2009, p. 1.

${ }^{56}$ STJ, $1^{\text {a }}$ Turma, REsp $n^{o}$ 148.072/RJ, Rel. Min. José Delgado, j. 27 nov. 1997. DJ 23 mar. 1998.

57 NUNES, Cleucio Santos. Curso Completo De Direito Processual Tributário. $2^{\text {a }}$ Ed. São Paulo: Saraiva Educação., 2018, p. 506-507.

${ }^{58}$ BARROSO Luís Roberto. O controle de constitucionalidade no direito brasileiro: exposição sistemática da doutrina e análise critica da jurisprudência. $6^{\mathbf{a}}$ ed. São Paulo: Saraiva, 2012, p. 1.
} 
controle de constitucionalidade pode ser feito em comparação não somente com normas diretamente inscritas na Constituição, mas também com "princípios não inscritos integrantes da ordem constitucional global" ${ }^{, 59}$.

Isto posto, vale levantar discussão proposta por Hugo de Brito Machado a diversos juristas, na obra "Repetição do indébito e compensação no Direito Tributário", editada no ano de 2001 e por ele organizada. Na ocasião, o primeiro questionamento feito aos juristas foi "O direito à restituição do tributo pago indevidamente tem fundamento na Constituição Federal, ou apenas no CTN?". De acordo com o organizador, a esta primeira pergunta, todos os autores responderam que o fundamento estava na Constituição - e assim completou:

\begin{abstract}
Na verdade, quando se pergunta se um direito tem fundamento na Constituição, não se está perquirindo a respeito de um fundamento remoto. Não se está questionando a respeito do fundamento de validade da norma que o instituiu, porque obviamente toda lei tem seu fundamento de validade na Constituição. O que se quer saber é se o direito nasce diretamente da Constituição e, desta forma, existe, mesmo na omissão completa do ordenamento infraconstitucional. O direito à restituição do que tenha o contribuinte pago indevidamente tem inegável fundamento na Constituição, na medida em que está garante que o tributo é devido na forma da lei e o legislador, por seu turno, está sujeito à limitações na definição do dever jurídico tributário. Assim, ainda que o ordenamento infraconstitucional nada estabeleça a respeito do direito à repetição de indébito, tal direito existirá, induvidosamente, por força dos preceitos da própria Constituição. É um corolário daquele direito de somente pagar o que seja devido nos termos da própria Constituição e das leis. Em sendo assim, como de fato é, tem-se uma outra conclusão inevitável e até óbvia em termos de lógica jurídica, de grande relevo. Se uma norma infraconstitucional nega o direito à restituição do indébito, ou a torna impraticável, será inconstitucional ${ }^{60}$.
\end{abstract}

Nesse diapasão, Cairon Ribeiro dos Santos entende que o direito, em sentido amplo, ao ressarcimento do indébito tributário, seja por meio de compensação, seja por meio de repetição de indébito, se apoia nos princípios constitucionais do direito à propriedade (art. $5^{\circ}, \mathrm{XXII}, \mathrm{CF} / 88$ ), do devido processo legal (art. $5^{\circ}, \mathrm{LIX}, \mathrm{CF} / 88$ ), da legalidade tributária (art. 150, I, CF/88) e da moralidade pública (art. 37, caput, CF/88) ${ }^{61}$.

Adiciona-se, também, a capacidade contributiva (art. 145, §1, $\mathrm{CF} / 88$ ), a responsabilidade objetiva do Estado (art. $37, \S 6^{\circ}, \mathrm{CF} / 88$ ) e a isonomia (art. $5^{\circ}$, caput, $\mathrm{CF} / 88$ ),

${ }^{59}$ CANOtilho, J. J. Gomes. Direito Constitucional e Teoria da Constituição. $7^{\mathrm{a}}$ ed. Coimbra: Edições Almedina, 2003, p. 919.

${ }^{60}$ MACHADO, Hugo de Brito (org.). Repetição do indébito e compensação no Direito Tributário. $1^{\mathrm{a}}$ ed. Fortaleza e São Paulo: Instituto Cearense de Direito Tributário (ICET) e Editora Dialética, 2001, p. 11.

${ }^{61}$ SANTOS, Cairon Ribeiro dos. Repetição do indébito, compensação e ação declaratória. In: MACHADO, Hugo de Brito (org.). Repetição do indébito e compensação no Direito Tributário. $1^{\mathrm{a}} \mathrm{ed}$, Cap. 4. Fortaleza e São Paulo: Instituto Cearense de Direito Tributário (ICET) e Editora Dialética, 2001, p. 73-74. 
como fundamentos da devolução de tributos indevidos. Para James Marins, "a devolução de valores pagos indevidamente, em qualquer caso, é reflexo precípuo de efetivação da justiça social, em conformidade com os parâmetros que norteiam a vida em sociedade"62.

Vê-se, pois, que os princípios que dão fundamento à repetição do indébito constituem o bloco constitucional, dentro da definição de Canotilho ${ }^{63} \mathrm{e}$, assim, podem servir de parâmetro para averiguar a constitucionalidade das normas-objeto $-\mathrm{o}$ art. $2^{\circ}$-B, Lei $\mathrm{n}^{\mathrm{o}}$ 9.494/1997 e o art. 1.059, CPC/2015. Nesse sentido,

\begin{abstract}
a principal consequência que se pode extrair de tal fundamento constitucional mas que, por vezes, é solenemente ignorada pelo Poder Judiciário - é a de que o direito à restituição de tributo pago indevidamente não pode ser suprimido, embaraçado ou impossibilitado pela legislação de inferior hierarquia. Não têm validade dispositivos de lei, seja ordinária ou complementar, que estabeleçam formalidades que, absolutamente desproporcionais, terminem representando pura e simplesmente um óbice ao exercício do direito à restituição ${ }^{64}$.
\end{abstract}

Em paralelo, apesar do aparente consenso jurisprudencial, poucas são, em verdade, as manifestações recentes dos tribunais brasileiros sobre o tema do cabimento de medidas liminares contra a Fazenda Pública em ações tributárias de repetição de indébito, em especial nos últimos dez anos. Isto sugere a necessidade de trazer o tema de volta a debate, submetendo-o à reapreciação do Poder Judiciário, em especial pelo advento do instituto das tutelas provisórias, com o CPC/2015.

De fato, o argumento de que as ações de repetição de indébito não comportariam medidas liminares em desfavor do Poder Público por força art. $2^{\circ}$-B, Lei no 9.494/1997 e do art. 1.059, CPC/2015, ecoam os óbices doutrinários do reexame necessário e do regime de precatórios, que, como exposto, restam superados pela doutrina e pela jurisprudência.

As principais constatações práticas desta superação são (i) o entendimento de que às decisões interlocutórias, como são as decisões liminares, não se aplica a exigência do reexame necessário, associada a sentenças ${ }^{65}$; (ii) o reconhecimento de que o advento da LC $n^{\text {o }}$ 104/2001, que acrescentou o inciso V ao art. 151, CTN, deixou claro que a concessão de tutelas provisórias contra a Fazenda Pública é possível em matéria tributária ${ }^{66}$; (iii) o

\footnotetext{
${ }^{62}$ MARINS, James. Direito Processual Tributário Brasileiro - Administrativo e Judicial. 12a ed. São Paulo: Thomson Reuters Brasil, 2019, p. 502-503.

${ }^{63}$ CANOTIlHO, J. J. Gomes. Direito Constitucional e Teoria da Constituição. $7^{\mathrm{a}}$ ed. Coimbra: Edições Almedina, 2003, p. 919.

${ }^{64}$ MACHADO SEGUNDO, Hugo de Brito. Processo Tributário. 10a ed. São Paulo: Atlas, 2018, p. 442.

${ }^{65}$ STJ, 6a Turma, REsp $n^{o}$ 659.200/DF, Rel. Min. Hélio Quaglia Barbosa, j. 21 set. 2004. DJ 11 out. 2004.

${ }^{66}$ STJ, $2^{\text {a }}$ Turma, REsp $n^{o} 716.379 / R N$, Rel. Min. Franciulli Netto, j. 03 mar. 2005, DJ 22 ago. 2005.
} 
reconhecimento de que, às obrigações definidas em lei como de pequeno valor, não se aplica o sistema de precatórios, visto que são pagas por meio de RPV, na forma do art. $100, \S 3^{\circ}$, $\mathrm{CF} / 88^{67}$; e (iv) o reconhecimento da permissão ao bloqueio de verbas públicas, como medida assecuratória atípica fundada no poder geral de cautela do juiz ${ }^{68}$.

É significativo ressaltar, também, que o STJ já considera que o art. $2^{\circ}$-B, Lei $n^{\circ}$ 9.494/1997, deve ser interpretado restritivamente, como restou consignado no REsp $\mathrm{n}^{\circ}$ 775.618/RS, inclusive no que tange à execução provisórias de sentenças ${ }^{69}$. A partir deste entendimento, novas possibilidades de afastamento dos obstáculos ao deferimento de medidas liminares contra a Fazenda Pública na restituição de indébitos vêm sendo aventadas pela jurisprudência.

No $A I n^{\circ}$ 5001145-88.2017.4.03.0000, por exemplo, o Tribunal Regional Federal da $3^{\text {a }}$ Região (TRF-3) entendeu que o direito à integralidade dos proventos de pensão por morte com efeitos prospectivos não se enquadra nas hipóteses de aplicação do referido dispositivo, em face da natureza alimentar da prestação e da necessidade de deferência ao princípio constitucional da dignidade da pessoa humana ${ }^{70}$.

Nos EDcl no AI nº 0025237-94.2012.4.03.0000, por sua vez, restou consignado que o afastamento do art. $2^{\circ}$-B, Lei n ${ }^{\circ}$ 9.494/1997 é possível em situações especialíssimas, relacionadas a evidente estado de necessidade, "sendo, pois, imperiosa a antecipação da tutela como condição, até mesmo, de sobrevivência para o jurisdicionado"71.

Paralelamente, entende-se que a tutela antecipada poderia, ao invés de ser utilizada para executar, desde logo, a Fazenda Pública, ser deferida para, somente, garantir a expedição dos precatórios, que ficariam depositados em juízo, no âmbito do processo, até o deslinde do feito. Isto reduziria o tempo de espera do credor para o recebimento do valor devido, caso o resultado lhe favorecesse ${ }^{72}$.

\footnotetext{
${ }^{67}$ STJ, $2^{\text {a }}$ Turma, REsp $n^{o}$ 853.880/RS, Rel. Min. Castro Meira, j. 19 set. 2006. DJ 28 set. 2006.

${ }^{68}$ STJ, $2^{\text {a }}$ Turma, AgRg no REsp no 935.083/RS, Rel. Min. Humberto Martins, j. 02 ago. 2007. DJ 15 ago. 2007.

${ }^{69} \mathrm{STJ}, 5^{\text {a }}$ Turma, REsp $n^{\circ}$ 775.618/RS, Rel. Min. Arnaldo Esteves Lima, j. 26 jun. 2007, DJ 06 ago. 2007.

${ }^{70}$ TRF-3, $2^{\mathrm{a}}$ Turma, AI n ${ }^{\circ}$ 5001145-88.2017.4.03.0000, Rel. Des. Federal Luiz Paulo Cotrim Guimarães, j. 11 abr. 2019, e-DJF3 15 abr. 2019.

${ }^{71}$ TRF-3, 6a Turma, EDcl no AI no 0025237-94.2012.4.03.0000, Rel. Des. Federal Diva Malerbi, j. 11 mai. 2017, e-DJF3 23 mai. 2017, p. 1.

${ }^{72}$ MACHADO, Hugo de Brito. Tutela jurisdicional antecipada na repetição de indébito trbutário. Repertório IOB de jurisprudência: tributário, constitucional e administrativo, v. 24, p. 450-452, 1995. Disponível em: <http://biblioteca2.senado.gov.br:8991/F/?func=itemglobal\&doc_library=SEN01\&doc_number=000502161 >. Acesso em: 01 mar. 2020.
} 
De fato, a permanência do valor depositado em juízo daria, à Fazenda Pública, a segurança necessária para que restasse afastado qualquer perigo de irreversibilidade da decisão que antecipa a tutela. A expedição liminar do correspondente precatório - ou, possivelmente, na sistemática atual, de uma RPV - aceleraria significativamente a efetivação do direito do contribuinte e não traria qualquer prejuízo efetivo ao Poder Público ${ }^{73}$.

Outro argumento relevante é a possibilidade de se utilizar a tutela provisória apenas para garantir o reconhecimento do direito à repetição de indébito. Esta já é uma possibilidade bem definida no âmbito do Mandado de Segurança objetivando compensação tributária, como se extrai da Súmula $\mathrm{n}^{\circ} 213, \mathrm{STJ}^{74}$.

Nesse sentido, verifica-se plausível a utilização analógica deste entendimento também para a repetição de indébito tributária. Isto é, em sede de cognição sumária, mesmo que não seja possível aferir a liquidez de determinado crédito, há possibilidade de "reconhecimento do direito in natura do contribuinte", inclusive, afastando-se quaisquer normas infralegais que constituam óbice à efetivação do direito de repetir o indébito ${ }^{75}$.

Ressalta-se, nesse diapasão, o AI no 0004424-80.2011.4.03.0000, apreciado pela Quinta Turma do TRF-3, no ano de 2011, em que se afastou o argumento da Fazenda Pública de que a discussão do ressarcimento em sede liminar seria incompatível com o sistema de precatórios do art. 100, CF/88. Definiu-se que, em face da natureza mandamental da sentença concessiva de segurança, não haveria que se temer ressarcimento prematuro dos valores ${ }^{76}$.

Tal reconhecimento, em sede liminar, do direito à restituição do indébito (desde que, por certo, verificados os requisitos autorizadores no caso concreto), poderia, inclusive, autorizar a já referida expedição liminar do correspondente precatório ou RPV, em nome da duração razoável e da efetividade processuais. Adicionalmente, sob uma perspectiva econômica, caso as regras orçamentárias representassem empecilho, o pagamento "poderia

\footnotetext{
${ }^{73}$ BUENO, Cássio Scarpinella. Liminar em mandado de segurança: um tema com variações. $2^{\mathrm{a}}$ ed. São Paulo: Editora Revista dos Tribunais, 1999, p. 34.

${ }^{74}$ STJ, $1^{a}$ Seção, Súmula n ${ }^{o}$ 213, j. 23 set. 1998, DJ 02 out. 1998. O mandado de segurança constitui ação adequada para a declaração do direito à compensação tributária.

${ }^{75}$ MARINS, James. Direito Processual Tributário Brasileiro - Administrativo e Judicial. 12a ed. São Paulo: Thomson Reuters Brasil, 2019, p. 597.

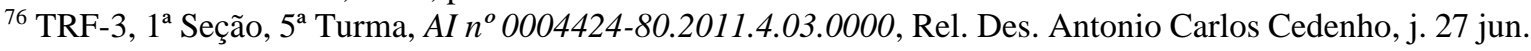
2011, e-DJF3 06 jul. 2011, p. 1.
} 
se dar à conta de créditos especiais abertos para dar cumprimento à decisão judicial antecipatória" 77 .

Em se tratando, pois, de repetição de indébito fundamentada (i) em precedentes do STF e do STJ, (ii) entendimento pacífico de outros órgãos Judiciários ou (iii) reconhecimento administrativo de que o tributo pago era indevido, se estará tratando de efeitos erga omnes, de modo que a restituição dos valores deveria, em uma situação ideal, se dar de ofício pela Fazenda Pública, visto que há evidência clara do direito do contribuinte.

Não sendo tal prática usual, no entanto, o deferimento de tutelas provisórias seria a medida que melhor simbolizaria a justiça no processo tributário. No mesmo diapasão, quando a restituição de indébito é decorrente de invalidação de norma tributária impositiva, declarada pelo STF, isso se equivale à própria expedição de título executivo, cuja liquidez é auferida na oportunidade em que o Poder Público se defende em sede de contestação ${ }^{78}$.

\section{CONCLUSÃO}

Retoma-se, finalmente, a provocação feita anteriormente, a respeito do REsp $n^{\circ}$ 148.072/RJ. Na ocasião, a Primeira Turma do STJ entendeu que, no campo tributário, a vedação à concessão de liminares contra a Fazenda Pública poderia ser afastada nos casos em que houvesse entendimento jurisprudencial uniformizado sobre a relação jurídica em debate $^{79}$. Este julgado, do ano de 1997, tratava de situação que, anos mais tarde, viria a se enquadrar perfeitamente na hipótese do art. 311, II, CPC/2015, ou seja, de deferimento de tutelas de evidência contra a Fazenda Pública, quando o argumento do autor estiver fundado em teses repetitivas dos tribunais superiores.

Com base no exposto no presente artigo, é possível concluir que, em verdade, são inaplicáveis quaisquer óbices à concessão de tutelas de evidência contra a Fazenda Pública, em sede de repetição de indébito tributário, quando a argumentação estiver fundada no art.

\footnotetext{
77 NUNES, Cleucio Santos. Curso Completo De Direito Processual Tributário. 2 ${ }^{\text {a }}$ Ed. São Paulo: Saraiva Educação., 2018, p. 505-507.

${ }^{78}$ Devida ressalva deve ser feita, por certo, à necessidade de atuação prudencial por parte do magistrado, de modo a garantir a oportunidade de o Poder Público contrapor os argumentos do autor, inclusive impugnando documentos comprobatórios ou valores apontados pelo contribuinte. Ainda assim, no entanto, a tutela antecipada deveria ser possível caso a defesa da Fazenda não fosse considerada suficiente para desconstituir as alegações e provas do autor (NUNES, Cleucio Santos. Curso Completo De Direito Processual Tributário. $2^{\mathrm{a}}$ Ed. São Paulo: Saraiva Educação., 2018, p. 505-506).

${ }^{79}$ STJ, $1^{\text {a }}$ Turma, REsp no 148.072/RJ, Rel. Min. José Delgado, j. 27 nov. 1997. DJ 23 mar. 1998.
} 
311, II e parágrafo único, CPC/2015. Nesses casos, se o conjunto probatório for suficientemente convincente, no entender do magistrado - ou seja, que se trata de evidência significativamente forte - é possível, inclusive, o deferimento da tutela provisória de evidência em caráter liminar ${ }^{80}$.

Com efeito, ao se observar que a própria Constituição Federal discrimina que o credor alimentar e o credor de pequeno valor estão sujeitos a regime mais célere de recebimento de crédito, também é possível concluir que, a partir do momento em que o credor tributário apresenta evidência de força significativa desde a petição inicial, também não é possível colocá-lo no mesmo patamar que o credor de qualquer valor, do qual o direito de crédito ainda depende de reconhecimento prévio em processo de conhecimento.

Da mesma forma, neste tipo de ação, também se aplicam as tutelas de urgência, desde que o autor, na petição inicial, requeira, ao invés do deferimento da restituição, o reconhecimento de que esta é devida, em analogia ao entendimento da Súmula no 213, STJ, para a compensação de créditos tributários.

Nestes casos, também é possível, sem prejuízos aos cofres públicos - e, portanto, em obediência ao princípio do interesse público - que o juiz autorize, em sede liminar, a expedição de precatório ou RPV, que ficaria depositado em juízo, no âmbito do processo, até o deslinde do feito. Dessa maneira, restariam contempladas a duração razoável e a efetividade processuais, em tudo homenageados, também, os princípios de celeridade e cooperação processuais, preconizados pela reforma legislativa que deu origem ao CPC/2015.

Por último, vale ressaltar que, face ao reconhecimento da constitucionalidade do direito à repetição de indébito, é necessário reconhecer que tais fundamentos podem servir de normas-parâmetro para averiguar a constitucionalidade do art. 2º $-B$, Lei n ${ }^{\circ}$ 9.494/1997, bem como do art. 1.059, CPC/2015, como normas-objeto. Tal verificação poderia, em sede de controle de constitucionalidade, justificar eventual revisão de posicionamento dos tribunais acerca do óbice que estes dispositivos representam ao deferimento de tutelas provisórias contra a Fazenda Pública, inclusive examinando-se a possibilidade de deferimento liminar deste tipo de pedido.

\footnotetext{
${ }^{80}$ MACHADO SEGUNDO, Hugo de Brito. Processo Tributário. 10a ed. São Paulo: Atlas, 2018, p. 442.
} 


\section{REFERÊNCIAS}

ALVES, Francisco Glauber Pessoa. A tutela antecipada em face da Fazenda Pública, seu perfil contemporâneo (tendências jurisprudenciais) e a necessidade de uma hermenêutica que lhe atribua efetividade. Revista de Processo, São Paulo: ano 28, n. 110, p. 37 a 71, 2003.

BARROSO, Luís Roberto. Curso de Direito Constitucional contemporâneo: os conceitos fundamentais e a construção do novo modelo. $4^{\mathrm{a}}$ ed. São Paulo: Saraiva, 2013.

BARROSO Luís Roberto. O controle de constitucionalidade no direito brasileiro: exposição sistemática da doutrina e análise critica da jurisprudência. $6^{\mathbf{a}}$ ed. São Paulo: Saraiva, 2012.

BRASIL. Superior Tribunal de Justiça. Recurso Especial. [...]. REsp $n^{\circ}$ 171.258/SP: Sexta Turma, STJ. Rel. Min. Anselmo Santiago. Brasília, j. 10 nov. 1998. DJ 18 dez. 1998a. Disponível

em: <https://ww2.stj.jus.br/processo/ita/documento/mediado/?num_registro=1998002598 13\&dt_publicacao=18-12-1998\&cod_tipo_documento=3>. Acesso em: 29 fev. 2020. . Superior Tribunal de Justiça. Recurso Especial. [...]. REsp n $n^{\circ}$ 148.072/RJ: Primeira Turma, STJ. Rel. Min. José Delgado. Brasília, j. 27 nov. 1997. DJ 23 mar. 1998b. Disponível em: <https://ww2.stj.jus.br/processo/ita/documento/mediado/?num_registro=1997006464 32\&dt_publicacao=23-03-1998\&cod_tipo_documento=3 >. Acesso em: 29 fev. 2020. . Superior Tribunal de Justiça. Enunciado no 213 da Súmula do STJ. O mandado de segurança constitui ação adequada para a declaração do direito à compensação tributária. Súmula $n^{o}$ 213: Primeira Seção, STJ. Brasília, j. 23 set. 1998, DJ 02 out. $1998 \mathrm{c}$, p. 250 . Disponível em: <https://ww2.stj.jus.br/docs_internet/revista/eletronica/stj-revista-sumulas2011_16_capSumula213.pdf>. Acesso em 29 fev. 2020.

. Superior Tribunal de Justiça. Agravo Regimental em Recurso Especial. [...]. AgRg no REsp n $n^{o}$ 221.014/PE: Primeira Turma, STJ. Rel. Min. José Delgado. Brasília, j. 05 out. 1999. DJ 29 nov. 1999a. Disponível em: 
<https://ww2.stj.jus.br/processo/ita/documento/mediado/?num_registro=1999005776

47\&dt_publicacao=29-11-1999\&cod_tipo_documento=3>. Acesso em: 29 fev. 2020.

Superior Tribunal de Justiça. Recurso Especial. [...]. REsp $n^{\circ}$ 188.974/MS:

Primeira Turma, STJ. Rel. Min. Garcia Vieira. Brasília, j. 04 mar. 1999. DJ 03 mai. 1999b.

Disponível

em:

<https://ww2.stj.jus.br/processo/ita/documento/mediado/?num_registro=1998006909

72\&dt_publicacao=03-05-1999\&cod_tipo_documento=3>. Acesso em: 29 fev. 2020.

. Supremo Tribunal Federal. Reclamação. [...]. Rcl $n^{o}$ 1.514/RS: Decisão

Monocrática, STF. Rel. Min. Celso de Mello. Brasília, j. 05 jun. 2000. DJ 19 jun. 2000.

Disponível

em:

$<$ http://stf.jus.br/portal/diarioJustica/verDiarioProcesso.asp?numDj=117\&dataPublic acaoDj=19/06/2000\&incidente $=3726856 \& \operatorname{codCapitulo}=6 \&$ numMateria=95\&codMat eria=2>. Acesso em: 29 fev. 2020.

Superior Tribunal de Justiça. Recurso Especial. [...]. REsp $n^{o}$ 463.778/RS: Sexta Turma, STJ. Rel. Min. Vicente Leal. Brasília, j. 26 nov. 2002. DJ 19 dez. 2002, p. 504. Disponível em: $<$ https://ww2.stj.jus.br/processo/revista/documento/mediado/?componente=ATC\&se quencial $=588472 \&$ num_registro $=200201127998 \&$ data $=20021219 \&$ tipo $=51 \&$ format o=PDF $>$. Acesso em: 29 fev. 2020.

Supremo Tribunal Federal. Medida Cautelar em Ação Direta de Inconstitucionalidade. [...]. MC na ADI $n^{o}$ 1.576/DF: Plenário do STF. Rel. Min. Marco Aurélio. Brasília, j. 16 abr. 1997. DJ 06 jun. 2003. Disponível em: <http://redir.stf.jus.br/paginadorpub/paginador.jsp?docTP=AC\&docID=347137>. Acesso em: 29 fev. 2020.

. Superior Tribunal de Justiça. Recurso Especial. [...]. REsp $n^{\circ}$ 638.919/RS: Quinta Turma, STJ. Rel. Min. Felix Fischer. Brasília, j. 23 jun. 2004, DJ 09 ago. 2004a. Disponível em: $<$ https://ww2.stj.jus.br/processo/revista/documento/mediado/?componente=ATC\&se quencial=1303073\&num_registro=200400230733\&data=20040809\&tipo=51\&forma to=PDF $>$. Acesso em: 29 fev. 2020. 
. Superior Tribunal de Justiça. Recurso Especial. [...]. REsp $n^{o}$ 659.200/DF: Sexta

Turma, STJ. Rel. Min. Hélio Quaglia Barbosa. Brasília, j. 21 set. 2004. DJ 11 out. $2004 b$.

em:

$<$ https://ww2.stj.jus.br/processo/revista/documento/mediado/?componente=ATC\&se quencial=1405063\&num_registro=200400509040\&data=20041011\&tipo=91\&forma to=PDF $>$. Acesso em: 29 fev. 2020.

Superior Tribunal de Justiça. Recurso Especial. [...]. REsp $n^{o} 716.379 / R N$ : Segunda Turma, STJ. Rel. Min. Franciulli Netto. Brasília, j. 03 mar. 2005, DJ 22 ago. 2005 .

Disponível

em:

$<$ https://ww2.stj.jus.br/processo/revista/documento/mediado/?componente=ATC\&se quencial $=1653186 \&$ num_registro $=200500028315 \&$ data $=20050822 \&$ tipo $=91 \&$ forma to=PDF $>$. Acesso em: 29 fev. 2020.

. Superior Tribunal de Justiça. Recurso Especial. [...]. REsp $n^{\circ} 853.880 / R S$ : Segunda Turma, STJ. Rel. Min. Castro Meira. Brasília, j. 19 set. 2006. DJ 28 set. 2006. Disponível

em: $<$ https://ww2.stj.jus.br/processo/revista/documento/mediado/?componente=ATC\&se quencial $=2568572 \&$ num_registro $=200601357152 \&$ data $=20060928 \&$ tipo $=91 \&$ forma to=PDF $>$. Acesso em: 29 fev. 2020.

. Superior Tribunal de Justiça. Agravo Regimental em Recurso Especial. [...]. AgRg no REsp $n^{o}$ 935.083/RS: Segunda Turma, STJ. Rel. Min. Humberto Martins. Brasília, j. 02 ago. 2007. DJ 15 ago. 2007a. Disponível em: $<$ https://ww2.stj.jus.br/processo/revista/documento/mediado/?componente=ATC\&se quencial $=3183154 \&$ num_registro $=200700571932 \&$ data $=20070815 \&$ tipo $=91 \&$ forma to=PDF $>$. Acesso em: 29 fev. 2020.

. Superior Tribunal de Justiça. Recurso Especial. [...]. REsp $n^{\circ} 775.618 / R S$ : Quinta Turma, STJ. Rel. Min. Arnaldo Esteves Lima. Brasília, j. 26 jun. 2007, DJ 06 ago. 2007b. Disponível em: $<$ https://ww2.stj.jus.br/processo/revista/documento/mediado/?componente=ATC\&se quencial $=3137758 \&$ num_registro $=200501383195 \&$ data $=20070806 \&$ tipo $=91 \&$ forma to=PDF $>$. Acesso em: 29 fev. 2020. 
. Superior Tribunal de Justiça. Recurso Especial. [...]. REsp $n^{o}$ 1.085.257/SP:

Segunda Turma, STJ. Rel. Min. Eliana Calmon. Brasília, j. 09 dez. 2008. DJe 24 mar. 2009a.

$<$ https://ww2.stj.jus.br/processo/revista/documento/mediado/?componente=ATC\&se quencial $=4443249 \&$ num_registro=200801983081\&data $=20090324 \&$ tipo $=51 \&$ forma to=PDF $>$. Acesso em: 29 fev. 2020.

Tribunal Regional Federal da $5^{\text {a }}$ Região. Embargos de Declaração em Apelação Cível. [...]. EDcl em Apelação Cível no 0021402-72.2004.4.05.8100/02: Segunda Turma, TRF-5. Rel. Des. Francisco Barros Dias. Recife, j. 28 abr. 2009. DJ 20 mai. 2009b. Disponível em: <http://www5.trf5.jus.br/processo/20048100021402502>. Acesso em: 29 fev. 2020.

- Supremo Tribunal Federal. Medida Cautelar em Ação Direta de Inconstitucionalidade. [...]. MC na ADI $n^{o}$ 2.356/DF: Plenário do STF. Rel. Min. Néri da Silveira, Rel. p/ Acórdão Min. Ayres Britto. Brasília, j. 25 nov. 2010. DJe 19 mai. 2011a. Disponível em: <http://redir.stf.jus.br/paginadorpub/paginador.jsp?docTP=AC\&docID=623127> . Acesso em: 29 fev. 2020.

. Tribunal Regional Federal da $3^{\mathrm{a}}$ Região. Agravo de Instrumento. [...]. AI $n^{o}$ 0004424-80.2011.4.03.0000: Quinta Turma da Primeira Seção, TRF-3. Rel. Des. Antonio Carlos Cedenho. São Paulo, j. 27 jun. 2011, e-DJF3 06 jul. 2011b. Disponível em: <http://web.trf3.jus.br/acordaos/Acordao/BuscarDocumentoGedpro/1413222>. Acesso em: 29 fev. 2020.

Supremo Tribunal Federal. Ação Direta de Inconstitucionalidade. [...]. ADI $n^{o}$ 4.425/DF: Plenário do STF. Rel. Min. Ayres Britto, Rel. p/ Acórdão: Min. Luiz Fux. Brasília, j. 14 mar. 2013. DJe 19 dez. 2013. Disponível em: <http://redir.stf.jus.br/paginadorpub/paginador.jsp?docTP=TP\&docID=5067184>.

Acesso em: 29 fev. 2020.

Supremo Tribunal Federal. Ação Direta de Constitucionalidade. [...]. ADC $n^{o}$ 04/DF: Plenário do STF. Rel. Min. Sydney Sanches. Rel. p/ Acórdão Min. Celso de Mello. Brasília, j. 01 out. 2008. DJe 30 out. 2014a. Disponível em: 
<http://redir.stf.jus.br/paginadorpub/paginador.jsp?docTP=AC\&docID=630103> .

Acesso em: 29 fev. 2020.

. Supremo Tribunal Federal. Ação Direta de Inconstitucionalidade. [...]. ADI $n^{o}$

4.357/DF: Plenário do STF. Rel. Min. Ayres Britto. Rel. p/ Acórdão Min. Luiz Fux.

Brasília, j. 14 mar. 2013. DJe 26 set. 2014b. Disponível em: $<$ http://redir.stf.jus.br/paginadorpub/paginador.jsp?docTP=TP\&docID=6812428>.

Acesso em: 29 fev. 2020.

. Supremo Tribunal Federal. Recurso Extraordinário. [...]. RE $n^{o}$ 573.872/RS:

Plenário do STF. Rel. Min. Edson Fachin. Brasília, j. 24 mai. 2017. DJe 11 set. 2017a.

Disponível

em:

<http://portal.stf.jus.br/processos/downloadPeca.asp?id=312690275\&ext=.pdf >.

Acesso em: 29 fev. 2020.

. Tribunal Regional Federal da $3^{\text {a }}$ Região. Embargos de Declaração em Agravo de

Instrumento. [...]. EDcl no AI no 0025237-94.2012.4.03.0000: Sexta Turma, TRF-3.

Rel. Des. Federal Diva Malerbi. Rio de Janeiro, j. 11 mai. 2017, e-DJF3 23 mai. 2017b.

Disponível

em:

<http://web.trf3.jus.br/acordaos/Acordao/BuscarDocumentoGedpro/6047672>.

Acesso em: 29 fev. 2020.

. Tribunal Regional Federal da $3^{\text {a }}$ Região. Agravo de Instrumento. [...]. AI n ${ }^{o}$ 5001145-88.2017.4.03.0000: Segunda Turma, TRF-3. Rel. Des. Federal Luiz Paulo Cotrim Guimarães. Rio de Janeiro, j. 11 abr. 2019, e-DJF3 15 abr. 2019. Disponível em: <http://web.trf3.jus.br/base-textual/Home/ListaColecao/9?np=1>. Acesso em: 29 fev. 2020.

BUENO, Cássio Scarpinella. Liminar em mandado de segurança: um tema com variações. $2^{a}$ ed. São Paulo: Editora Revista dos Tribunais, 1999.

BUENO, Cássio Scarpinella. Novo Código de Processo Civil Anotado. $3^{\mathrm{a}}$ ed. São Paulo: Saraiva, 2017.

CAIS, Cleide Previtalli. O processo tributário. $8^{\mathrm{a}}$ ed. São Paulo: Revista dos Tribunais, 2013.

CANOtIlHO, J. J. Gomes. Direito Constitucional e Teoria da Constituição. $7^{\mathrm{a}}$ ed. Coimbra: Edições Almedina, 2003. 
DIAS, Jean Carlos. Tutelas provisórias no novo CPC: tutelas de urgência: tutela de evidência. $2^{\text {a }}$ ed. Salvador: Juspodivm, 2018.

LOPES, João Batista. Tutela antecipada no processo civil brasileiro. $3^{\text {a }}$. ed. São Paulo: Editora Revista dos Tribunais, 2007.

MACHADO SEGUNDO, Hugo de Brito. Processo Tributário. 10a ed. São Paulo: Atlas, 2018.

MACHADO, Hugo de Brito (org.). Repetição do indébito e compensação no Direito Tributário. $1^{\mathrm{a}}$ ed. Fortaleza e São Paulo: Instituto Cearense de Direito Tributário (ICET) e Editora Dialética, 2001.

MACHADO, Hugo de Brito. Tutela jurisdicional antecipada na repetição de indébito trbutário. Repertório IOB de jurisprudência: tributário, constitucional e administrativo, v. 24, p. 450-452, dez. 1995. Disponível em: $<$ http://biblioteca2.senado.gov.br:8991/F/?func=itemglobal\&doc_library=SEN01\&doc_number=000502161>. Acesso em: 01 mar. 2020.

MARINONI, Luiz Guilherme. Direito Fundamental de Ação. In: CANOTILHO, J. J. G., et al. Comentários à Constituição do Brasil. 2a ed. São Paulo: Saraiva Educação, 2018.

MARINONI, Luiz Guilherme; ARENHART, Sérgio Cruz. Curso de Processo Civil: Processo de Conhecimento. 12 a ed. São Paulo: Revista dos Tribunais, v. 2, 2014.

MARINONI, Luiz Guilherme; MITIDIERO, Daniel. Direito fundamental à tutela adequada e efetiva. In: SARLET, I. W.; MARINONI, L. G.; MITIDIERO, D. Curso de Direito Constitucional. $8^{a}$ ed, Cap. 5.3. São Paulo: Saraiva Educação, 2019.

MARINS, James. Direito Processual Tributário Brasileiro - Administrativo e Judicial. 12a ed. São Paulo: Thomson Reuters Brasil, 2019.

MARTINS, Leonardo. Direito Fundamental à Igualdade. In: CANOTILHO, J. J. G., et al. Comentários à Constituição do Brasil. 2. ed. São Paulo: Saraiva Educação, 2018, p. 223-236.

MILLER, Cristiano Simão. Art. 1.059. In: ALVIM, A. A., et al. Comentários ao Código de Processo Civil - Lei n. 13.105/2015. 2ª ed. São Paulo: Saraiva, 2017. p. 1258-1259.

NUNES, Cleucio Santos. Curso Completo de Direito Processual Tributário. $2^{\mathrm{a}}$ ed. São Paulo: Saraiva Educação, 2018. 
SANTOS, Cairon Ribeiro dos. Repetição do indébito, compensação e ação declaratória. In:

MACHADO, Hugo de Brito (org.). Repetição do indébito e compensação no Direito

Tributário. $1^{\mathrm{a}}$ ed, Cap. 4. Fortaleza e São Paulo: Instituto Cearense de Direito Tributário (ICET) e Editora Dialética, 2001, p. 73-86.

VEIGA, Daniel Brajal, et al. Tutela provisória: questões polêmicas. In: BUENO, C. S., et al. Tutela Provisória no CPC: dos 20 anos de vigência do art. 273 do CPC/1973 ao CPC/2015. $2^{a}$ ed. São Paulo: Saraiva Educação, 2018. Cap. 24, p. 481-567.

ZAVASCKI, Teori Albino. Antecipação de tutela. $2^{a}$ ed. São Paulo: Saraiva, 1999. 